\title{
Analysis of Influence on The Level of The Economy, Knowledge of Taxes, and Sanctions on Compliance with Land and Building Tax Payments in Rural and Urban Areas (PBB-P2)
}

\section{Analisis Pengaruh Ekonomi terhadap Pengetahuan Pajak dan Sanksi dalam Kepatuhan Pembayaran PBB Perdesaan dan Perkotaan (PBB-P2)}

\author{
Refi Pratiwi ${ }^{1}$, Mas Iman Kusnandar² \\ 1Universitas Sulan Ageng Tirtayasa \\ Email : refipratiwi@untirta.ac.id \\ 2Universitas Sulan Ageng Tirtayasa \\ Email: imankusnandar28@gmail.com
}

\begin{abstract}
The purpose of this study was to determine and analyze the level of the economy, knowledge of taxes, and sanctions on compliance with land and building tax payments in rural and urban areas (PBB-P2) for the people of Cadasari District, Pandeglang Regency. This research uses a quantitative approach. The data source used in this study is primary data; this research was taken by distributing questionnaires to the respondents, namely land and building taxpayers in Cadasari District, Pandeglang Regency. The data analysis method used in this study is multiple linear regressions (Multiple Regression Analysis). This analysis is intended to reveal the influence between several independent variables and the dependent variable. The population in this study was the people of Cadasari District who were registered as land and building taxpayers (PBB-P2) at the end of 2020, namely 2417 people, while the sample using Slovin's formula was determined as many as 44 samples. The results of the research on the hypothesis that part there is an influence on the level of the economy, knowledge of taxes and sanctions on compliance with the payment of Rural and Urban Land and Building Tax (PBB-P2) for the people of Cadasari District, Pandeglang Regency.
\end{abstract}

Keywords: Economic Level, Knowledge, Sanctions, and Compliance

\begin{abstract}
Penelitian bertujuan untuk mengetahui dan menganalisis tingkat ekonomi, pengetahuan pajak dan sanksi terhadap kepatuhan pembayaran pajak bumi dan bangunan perdesaan dan perkotaan (PBB-P2) masyarakat Kecamatan Cadasari Kabupaten Pandeglang. Penelitian ini menggunakan pendekatan kuantitatif. Sumber data yang digunakan adalah data primer, yang diambil dengan cara menyebarkan kuesioner kepada para responden yaitu Wajib Pajak Bumi dan Bangunan di Kecamatan Cadasari Kabupaten Pandeglang. Metode analisis data dalam penelitian ini menggunakan regresi liniear berganda (Multiple Regression Analysis). Analisis ini dimaksudkan untuk mengungkapkan pengaruh antara beberapa variabel bebas dengan variabel terikat. Populasi dalam penelitian ini adalah masyarakat Kecamatan Cadasari yang terdaftar Wajib Pajak Bumi dan Bangunan (PBB-P2) akhir tahun 2020 yaitu sebanyak 2417 orang sedangkan sampel dengan menggunakan rumus Slovin ditetapkan sebanyak 44 sampel. Hasil penelitian pada hipotesis secara parsial terdapat pengaruh tingkat ekonomi, pengetahuan pajak
\end{abstract}


dan sanksi terhadap kepatuhan pembayaran Pajak Bumi dan Bangunan Perdesaan dan Perkotaan (PBB-P2) masyarakat Kecamatan Cadasari Kabupaten Pandeglang.

Kata kunci: Tingkat Ekonomi, Pengetahuan, Sanksi dan Kepatuhan

\section{INTRODUCTION}

The administration of the Republic of Indonesia (NKRI) is divided into provinces, districts, and cities. Each of these regions has the right and obligation to control and manage government affairs by themselves to increase the efficiency and effectiveness of government administration and services to citizens. Based on Law No. 28 of 2009 concerning Regional Taxes and Regional Levies, PBB, which was a central tax, has now been transferred to districts or cities as regional taxes. Starting January 1 , 2014, all districts or cities are required to take care of village and city land and building taxes (PBBP2), so that the regions have full responsibility for managing the village and city land and building taxes, currently managing land and building taxes. not the Primary Tax Service Office, but the Financial Management and Legacy Revenue Service.

Taxes are an obligation to surrender part of the wealth to the state treasury because of conditions, events, and actions that share a certain role, but not as a punishment, for regulations that are formalized by the government and can be implemented, but do not exist. reciprocal services directly from the state to protect the common good (Siti Resmi,. 2017).

Collection of Rural and Urban Land and Building Tax (PBB-P2) is a series of activities ranging from data collection of tax objects and subjects, determining the amount of taxes owed, collecting taxes from must be taxed, and monitoring of their deposits. PBB-P2 is a tax on land and/or buildings owned, controlled, and/or utilized by private persons or entities, except for areas used for plantation, forestry, and mining business activities (Regulation of the Regent of Pandeglang Number 39 of 2017).

The object of Land and Building Tax is divided into 2 components, namely the Earth which contains the surface of the earth, and the earth body which is located underneath it, on the other hand, the building is a construction method on the ground and is placed on the ground constantly or in water areas, on the other hand, the tax subject is a person or entity that has real rights to the land and buildings (A. Budiarto,. 2016).

High compliance from taxpayers is needed for smooth tax collection. Likewise, in the collection of land and building tax, high compliance from the WP PBB-P2 is also required. Taxpayer compliance is a condition where the taxpayer fulfills all tax obligations and exercises his taxation rights (Rahayu, Siti Kurnia, 2010). Taxpayer Compliance or compliance in taxation is a condition in which the taxpayer fulfills all tax obligations and exercises his taxation rights. (Warouw, J. Z. S., Sondakh, J. J., \& Walandouw, S. K. 2015). People who obey in paying taxes can be influenced by the factor of awareness so that people are aware of their responsibilities and obey the rules voluntarily (Hasibuan, M. 2016).

The economic level of the individual also provides a large enough influence for an individual to be able to meet his needs and to behave. Economic conditions are the position or position of a person in a human group which is determined by the type of economic activity, income, level of education, type of residence, and position in the organization. Economic conditions that describe the level of a person's economic status can show their position in social life. From his position in the social environment, then it has an impact on the individual concerned to behave. The economic capability possessed by taxpayers can be related to tax payment compliance. Economic level indicators include the ability to meet needs, the ability to save, and personal tendencies to buy goods (Putri dan Isgiyarta. 2013).

The low level of taxpayer compliance and public trust in the administration of tax management is due to a lack of public knowledge of ever-developing tax policies and regulations. knowledge of taxation is a taxpayer who knows and understands tax regulations. Ownership of NPWP for every taxpayer who has a taxpayer's income to register from obtaining NPWP as a means of administering the tax. (Siti Nurlaela, 2013).

This proves that taxpayers in Indonesia need more concrete socialization to increase their compliance in paying taxes. This will have an impact on increasing public confidence in the 
distribution of tax results that have been carried out according to applicable regulations, namely for the welfare of the people. So that the perception of taxpayers about tax payments will be positive for the government in managing the taxes they have paid. The knowledge factor is very important in helping taxpayers carry out their obligations, especially knowledge of taxes. Without knowledge, taxpayers will experience difficulties in registering themselves, filling out the Annual Notification Letter (SPT), and paying their taxes. Taxpayers who do not know about tax knowledge will be confused about how much tax should be paid. Indicators of tax knowledge are knowing the function of taxes, knowing the procedures or procedures for paying taxes, knowing tax penalties for late paying taxes, and knowing where to pay taxes (Wardani, Dewi Kusuma., dan Rumiyatun. 2017).

Another factor that affects individual taxpayer compliance in paying land and building taxes is tax sanctions. Tax sanctions are a guarantee that the provisions of taxation legislation (taxation norms) will be obeyed/obeyed/obeyed (Mardiasmo. 2011) or in other words, tax sanctions are a deterrent (preventive) so that taxpayers do not violate taxation norms. (Manalu. 2016). Some individual taxpayers who have not fulfilled their tax obligations will be subject to tax sanctions by applicable regulations. The existence of tax sanctions aims to make taxpayers pay taxes before the due date of payment. The lack of attention related to this administrative sanction makes individual taxpayers less disciplined in paying land and building taxes. The purpose of this study was to examine and analyze the effect of economic level, knowledge of taxes, and sanctions on compliance with land and building tax (PBB) payments for the people of Cadasari District, Pandeglang Regency.

\section{RESEARCH METHOD}

In this study, the author used quantitative research methods. Quantitative research methods can be interpreted as a research method based on the philosophy of positivism, used to research on certain populations or samples, sampling techniques are generally carried out randomly, data collection uses research instruments, data analysis is quantitative/statistical with the aim of testing hypotheses that are set (Sugiyono, 2014). The population in this study was the people of Cadasari District who were registered as land and building taxpayers at the end of 2020, namely 2417 taxpayers in Cadasari District. The sampling technique was determined using Slovin's formula, from a population of 2417 PBB taxpayers based on the results of these calculations with rounding, the sample was determined as many as 44 samples, namely the people who are registered in the Land and Building Tax (PBB) Cadasari District.

Data collection techniques used in this research are library research, field research in the form of observations, and questionnaires. The data source used in this research is primary data. Primary data is data taken directly from the first source in the object of research. The primary data source in this study was taken by distributing questionnaires to respondents, namely land and building taxpayers in Cadasari District, Pandeglang Regency. The data analysis method used in this study is multiple linear regressions (Multiple Regression Analysis). This analysis is intended to reveal the influence between several independent variables and the dependent variable. Data processing in this study used descriptive analysis with SPSS (Statistical Program for Social Science version 21 for Windows). The hypothesis test used is the t-test. This test is used to test one of the hypotheses in a study using multiple linear regression analysis. The t-test is used to partially test each variable, the results of the t-test can be seen in the coefficients table in the sig column. If $t$-value $>t$-table, it can be said that there is an influence between the independent variables and the dependent variable partially. If $\mathrm{t}$-value $<\mathrm{t}$-table, it can be said that there is no influence between the independent variables on the dependent variable partially. 


\section{RESULT AND DISCUSSION}

To test the significance of whether the previously established hypothesis is accepted or rejected, by comparing t-value with t-table. The results obtained from SPSS version 21 are:

\begin{tabular}{|c|c|c|c|c|c|c|}
\hline \multicolumn{7}{|c|}{ T-test (partial) } \\
\hline \multicolumn{7}{|c|}{ Coefficients $^{\mathbf{a}}$} \\
\hline \multirow[t]{2}{*}{ Model } & & \multicolumn{2}{|c|}{$\begin{array}{l}\text { Unstandardized } \\
\text { Coefficients }\end{array}$} & \multirow{2}{*}{$\begin{array}{c}\begin{array}{c}\text { Standardized } \\
\text { Coefficients }\end{array} \\
\text { Beta }\end{array}$} & \multirow{2}{*}{$\mathrm{t}$} & \multirow[b]{2}{*}{ Sig. } \\
\hline & & B & $\begin{array}{l}\text { Std. } \\
\text { Error }\end{array}$ & & & \\
\hline \multirow{4}{*}{1} & (Constant) & 1.917 & 3.491 & & .549 & .586 \\
\hline & Economic_Level (X1) & .258 & .102 & .346 & 2.529 & .016 \\
\hline & Knowledge_Level (X2) & .311 & .147 & .298 & 2.123 & .041 \\
\hline & Tax_Sanctions (X3) & .348 & .153 & .319 & 2.274 & .029 \\
\hline
\end{tabular}

\section{The Effect of the Economic Level on the Compliance of Rural and Urban Land and Building} Tax payments (PBB-P2)

The test results on hypothesis 1 on the effect of the economic level on compliance with the payment of Rural and Urban Land and Building Tax (PBB-P2) obtained the results of t-value $>\mathrm{t}-$ table $(2.529>2.028)$ with a significance level of $0.016(0.016<0.05)$ with the provisions of the first hypothesis. accepted then there is a significant effect of the economic level on compliance with the payment of Rural and Urban Land and Building Tax (PBB-P2) in the Cadasari District Community, Pandeglang Regency.

Economic status is the position of a person in society based on ownership of wealth. The economic condition of the taxpayer can be a motivational boost to be able to fulfill their PBB obligations (Gunadi, 2013). On the other hand, if a person has a high economic condition, the level of needs of that person will be more numerous and varied. The hierarchy of human needs expressed by Maslow explained that humans have a level of need that can distinguish each human being from the side of their welfare. The higher the human welfare, the higher the level to be fulfilled, and thus, the fulfillment of obligations will also be more diverse.

The results of this study are following the research of Putri and Isgiyarta (2013) which states that the results of their research have a positive and significant effect on tax compliance.

\section{The Influence of Knowledge Level on the Compliance of Rural and Urban Land and Building Tax payments (PBB-P2)}

The results of testing on hypothesis 2 on the effect of tax knowledge on compliance with the payment of Rural and Urban Land and Building Tax (PBB-P2) in the Cadasari District Community, Pandeglang Regency, obtained the results of $t$-value $>t$-table $(2.123>2.028)$ with a significance level of $0.041(0.041<0,05)$ provided that the third hypothesis is accepted, there is a significant effect of tax knowledge on compliance with the payment of Rural and Urban Land and Building Tax (PBB-P2) in the Cadasari District Community, Pandeglang Regency.

Tax knowledge is the process of changing the attitude and behavior of a taxpayer, or a group of taxpayers to mature humans through teaching and training efforts (Hardiningsih \& Yulianawati, 2011). The understanding of taxation regulations is everything related to taxation regulations, which have been determined by the Directorate General of Taxes, which the taxpayer has understood correctly and the taxpayer can carry out its obligations by general regulations and taxation procedures (Mustofa, et al. , 2016). The more taxpayers have an understanding and knowledge of tax regulations, the more taxpayer compliance will be in paying taxes.

The results of this study are following the research of Rosyida (2018) and Ayunda (2015) which state that the results of their research on tax knowledge have a positive and significant effect on taxpayer compliance in paying PBB. 


\section{The Effect of Tax Sanctions on Rural and Urban Land and Building Tax Payment Compliance (PBB-P2)}

The results of testing on hypothesis 3, there is an influence between the level of education, the level of the economy, and knowledge of taxes on compliance with the payment of Rural and Urban Land and Building Tax (PBB-P2) in the Community of Cadasari District, Pandeglang Regency, obtained F-value $>$ F-table $(2.274>2.874)$ with a significance level of $0.029(0.029<0.05)$ provided that the third hypothesis is accepted, there is a significant effect of tax sanctions on compliance with the payment of Rural and Urban Land and Building Tax (PBB-P2) in the Community of Cadasari District, Pandeglang Regency.

In the taxation provisions, there are 2 types of tax sanctions, namely: Administrative Sanctions and Criminal Sanctions. The basic regulations for the imposition of tax penalties on PBB are regulated in Article 38 and Article 39 of the KUP Law.

Administrative Sanctions of PBB - P2 are dependents or burdens other than Principal PBB - P2 which are payable in the form of a fine of $2 \%$ (two percent) per month for a maximum period of 24 (twenty-four) months as a result of late payment of PBB - P2; (Pandeglang Regent Regulation Number 88 of 2018). The heavier the tax sanctions imposed on taxpayers who violate the regulations, the more afraid the taxpayers will be to violate it so that it will increase taxpayer compliance in paying PBB.

The results of this study are following Isyatami's research (2019) which states that the results of his research are tax sanctions affecting taxpayer compliance in paying land and building taxes.

\section{CONCLUSION}

From the results of research conducted by the author, the authors conclude are: First. There is a significant effect of the economic level on compliance with the payment of Rural and Urban Land and Building Tax (PBB-P2) in the Cadasari District Community, Pandeglang Regency. Second, there is a significant effect of tax knowledge on compliance with the payment of Rural and Urban Land and Building Tax (PBB-P2) in the Cadasari District Community, Pandeglang Regency. Third. There is a significant effect of tax sanctions on compliance with the payment of Rural and Urban Land and Building Tax (PBB-P2) in the Cadasari District Community, Pandeglang Regency. Based on the above conclusions, the authors can provide the following suggestions: First. For the District Government, a) The District Government collaborates with the Bank to regularly come to the District Government Office every month to facilitate the payment process, b) Law enforcement efforts in the form of tax sanctions that can be imposed on taxpayers who violate taxation provisions, especially Land and Building Tax to be reaffirmed by the local District Government, c) The need for regular warnings so that taxpayers' awareness of fulfilling their obligations in a disciplined manner can be carried out properly. Second. For Taxpayers, a) Taxpayers should further improve their compliance in paying Land and Building Taxes before the due date of payment and use the speed of service at Banks that immediately get a Deposit Receipt (STTS), b) Increase understanding of the Land and Building Tax become a source of Regional Original Income (PAD) that can be used for regional development, c) Taxpayers need to pay attention to the provisions of sanctions received if they are late in paying taxes or do not pay Land and Building Taxes, d) Taxpayers need to increase their awareness motivation to pay taxes that tax revenues for the common welfare. For further researchers, a) Further research can add other variables that affect compliance with land and building tax (PBB) payments such as tax sanctions, taxpayer awareness, services, and taxpayer attitudes, b) Further research should expand the scope of research by adding research objects, namely conducting research not only in the district but in a wider area, including in the Tax Office (KPP) such as examining the influence of gender and education level on taxpayer compliance, c) Further research should expand the scope of research, such as in companies related to compliance. taxpayers such as the tax rate structure because of corporate taxpayer compliance.

\section{REFERENCE}

Budiarto, A. 2016. Practical Guidelines for Paying Taxes. Yogyakarta: Genesis Learning. Gunadi. 2013. Comprehensive Guide to Income Taxes. Jakarta: Bee Media Indonesia 
Hasibuan, M. 2016. Human Resource Management, Revised Edition. Yogyakarta: Bumi Aksara, p. 17

Manalu. 2016. The Influence of Awareness, Tax Sanctions, Level of Education and Fiscal Service on Taxpayer Compliance in Reporting Restaurant Taxes in Pekanbaru City. JOM Fekon. Vol. 3 No.1

Mardiasmo. 2011. Revised Edition Taxation. Yogyakarta: Andi Offset, p. 59

Mardoni, 2017. Land and Building Tax Management Policy for Rural and Urban Revenue, Financial Management and Regional Assets of Musi Rawas Regency. Journal of Humanities Social Education Research. Vol. 2. No. 2

Ma'ruf, M. H., \& Supatminingsih, S. 2019. Factors Affecting Taxpayer Compliance in Paying Land and Building Tax. Journal of Accounting and Tax, Vol. 5 No. June 1st.

Nurlaela, Siti. 2013. The Influence of Knowledge and Understanding, Awareness, Perception on Willingness to Pay Taxes for Individual Taxpayers Doing Free Work. Paradigm Journal. Vol. 11 No. 02 August 2013 - January 2014: 89-101.

Pandeglang Regent Regulation Number 88 of 2018 concerning Reduction and Abolition of Administrative Sanctions for Rural and Urban Land and Building Taxes

Putri and Isgiyarta. 2013. Analysis of the Effect of General Knowledge, Economic Level, and Tax Knowledge on Village and City Community PBB Compliance with Moderating Control Variables of Village / Kelurahan Officers (Case Study in Demak Regency). Diponegoro Journal Of Accounting. Volume 2, Number 3.

Rahayu, Siti Kurnia, 2010. Indonesian Taxation: Formal Concepts and Aspects, Yogyakarta: Graha Ilmu.

Regulation of the Regent of Pandeglang Number 39 of 2017 concerning the System and Procedure for Collecting Rural and Urban Land and Building Taxes in Pandeglang Regency

Resmi, Siti. 2017. Taxation Theory and Cases. Salemba Empat. Jakarta.

Sugiyono, 2014. Quantitative Research Methods, qualitative and R \& D. Alfabeta: Bandung

Wardani, Dewi Kusuma., And Rumiyatun. 2017. The Influence of Taxpayer Knowledge, Taxpayer Awareness, Motor Vehicle Tax Sanski, and Drive-Thru Samsat System on Motor Vehicle Taxpayer Compliance. Journal of Accounting Vol. 5 No. June 1, 2017: 15-24.

Warouw, J. Z. S., Sondakh, J. J., \& Walandouw, S. K. 2015. The effect of tax socialization and tax sanctions on corporate taxpayer annual SPT reporting compliance (Case study on KPP Pratama Bitung). Journal of EMBA: Journal of Economic Research in Business Management and Accounting, 3 (4), 585-592. 